Publisher homepage: www.universepg.com, ISSN: 2707-4641 (Online) \& 2707-4633 (Print)

https://doi.org/10.34104/ijma.020.061073

International Journal of Management and Accounting

Journal homepage: www.universepg.com/journal/ijma

\title{
Factors Affecting Visitors Satisfaction: An Empirical Study on the Paharpur Buddha Vihara, Naogaon, Rajshahi
}

\author{
Sazu Sardar ${ }^{1 *}$, Md. Enayet Hossain ${ }^{2}$, Md. Ikbal Hossain ${ }^{3}$, and Md. Shakibul Shaheen ${ }^{4}$ \\ ${ }^{1 \& 2}$ Dept. of Tourism and Hospitality Management, University of Rajshahi, Rajshahi, Bangladesh; ${ }^{3}$ Dept. of Marketing, \\ University of Rajshahi, Rajshahi, Bangladesh; and ${ }^{4}$ Dept. of Brand Management, PRAN-RFL Group, Bangladesh. \\ *Correspondence: sazu.thm@ru.ac.bd (Sazu Sardar, Lecturer, Dept of Tourism and Hospitality Management, University \\ of Rajshahi, Rajshahi, Bangladesh).
}

\begin{abstract}
With the advancement of the tourism industry, the importance of research on visitor satisfaction has been increasing as of recent years. The prime objective of current study is to explore the factors influencing visitor satisfaction from the perspective of archaeological sites, in Bangladesh. A thorough and wellconstructed research design is administered to analyze 200 data collected from the visitors having experience in visiting Paharpur Buddha Vihara. From the data, we conducted an extensive analysis to find out the main factors which influence visitor satisfaction. It is recognized that there are some essential factors; destination attractions, safety and security, favorable environment, food attraction and cost at said destination. These factors significantly influence visitor satisfaction. It is expected that the outcome of the study will support the tourism practitioners in planning and development for successful business operations. The paper concludes with some implications and future research directions.
\end{abstract}

Keywords: Visitor satisfaction, Archaeological tourism, Empirical study, and Destination sustainability.

\section{INTRODUCTION:}

Tourism is the largest industry in the world in terms of revenue and employment generation. In spite of global economic uncertainty from the recent past, the tourism industry remains stable and is positively growing in recent years (Vetitnev et al., 2013). According to the World Travel and Tourism Council (WTTC) in 2018, Travel \& Tourism contributed total US\$2750.7 billion to world GDP, representing $3.2 \%$ of global GDP. The sector supported 1 in 11 jobs in the earth. The industry grew by $10.4 \%$ in 2018 and the most mentionable part is that this positive growth is continuing in the 6th consecutive year. Again it was forecasted that travel \& tourism will grow by $3.6 \%$ in 2019 and up to January 2020 the global international tourists are grown by $3.8 \%$. This is a positive scenario of growth according to the forecasting of 2019. Tourism in Bangladesh has been emerged as a small but rapidly growing sector in the

UniversePG I www.universepg.com economy since the 1990s (Roy \& Roy, 2015). In the recent years, the contribution of tourism industry to the national economy has been increased significantly. According to the country annual report of WTTC (2019), the total contribution of Travel \& Tourism to GDP was $4.4 \%$ of total GDP in 2018 and this sector supported by $3.9 \%$ of total employment. Moreover in 2018 Travel \& Tourism visitor exports generated $0.8 \%$ of total exports. In 17 April 2018 Deputy Inspector General (DIG) of Tourist Police Sohrab Hossain published statistical data collected from around 800 tourist spots in Bangladesh that the number of domestic tourists stood at around 90,000 which has increased to 3.5 crore in 2017 while the number of foreign tourists has increased from 16,000 to 106,000 . The data expressed the potentiality of booming up the tourism and hospitality industry.

Bangladesh is called beauty queen for her beauty and attraction. She have the world longest sea beach 
Cox's Bazar, world famous mangrove forest Sundarban and cultural heritages. For cultural heritage or archaeological sites she is also called a country of ancient terrain full of historical attractions (Rahman, 2012). We can see from the early history of Bengal that the ruling dynasties such as the Pala rulers and Deva Kings gave out royal patronage to the Buddhists. An abundant amount of wellestablished and self-sufficient monasteries sprung up as a result of this patronage (Tuhin \& Mojumder, 2011). After the independence of Bangladesh in 1971 the government of Bongodondhu Sheikh Mujibur Rahman undertook some field projects for dis-covering undiscovered areas and they run a fairly ambitious scheme of excavations on selected sites. At present the exploration is hardly seen but the project has already discovered many historical and archaeological sites (Hasan et al., 2013).

The Paharpur Buddhist Viharais a noteworthy discovery of the project. It is $141 \mathrm{~km}$ far from Rajshahi division and is situated in small village Paharpur of north-west district Naogaon, Bangladesh. In 1985 UNESCO declared this place as world heritage site. This 7 th century archaeological site covers approximately an area of 27 acres of land. The entire establishment occupying a quadrangular court of $900 \mathrm{ft}$. externally on each side and has high enclosure-walls about $16 \mathrm{ft}$. in thickness and $12 \mathrm{ft}$. to $15 \mathrm{ft}$. in height. There are 177 rooms comprising of 45 cells in the north and 44 in the east west and south sections with a well-planned gateway complex on the north. Due to the influence of other temples of south and south east Asia, we can see a temple embracing the pyramidal cruciform structure (Tuhin $\&$ Mojumder, 2011). Since ancient times, the entire region of Bengal (including the Paharpur Buddhist Vihara) is one of the vital links between India and Southeast Asia because of its geographical location (UNESCO, 2018). The destination has mentionable contribution to local and national economy. Government earns revenue from the destination as entrance fee. The local citizens earn revenue from 53 different small businesses like restaurant, showpiece items, cottage rent, established around the destination. Usually everyday 1000 visitors visit this place. In winter season about 3000 visitors visit every day. Students from different educational institution come to visit this archaeological site as part of study tour. Beside this, many visitors come with their family members in different occasions.

UniversePG I www.universepg.com
When visiting the destination, visitors interact with different components of the destination, which as a whole, offers a package of diverse attributes which is not only limited to the stunning sceneries or historical reference and value of those who previously resided there, but also includes facilities and services which cater to the everyday needs of the visitor. The interacted components or factors affect visitor satisfaction. The purpose of this paper is to identify factors affecting visitors' satisfaction and to determine the level of visitors' satisfaction in respect of an archeological site Paharpur Buddha Vihara.

\section{Significance of the Study}

Satisfied visitors help tourism marketers to increase visitor providing the message from self-interest. There are also the underlying factors for building sustainable tourism destination. But it is the first task to know the factors which satisfied visitors. This study has significance contribution to identify the influencing factors that affect visitor satisfaction. This research will also helpful on tourism decision making process considering the influential factors for visitor satisfaction. The result of the study may substantially contribute to managerial understanding of visitor satisfaction. At the theory level, this study is able to produce greater understanding of the variables/factors that appear to be most responsible in structuring visitor satisfaction of a destination. In reality the result of this study will provide managers with greater insight concerning the potential benefits associated with visitor satisfaction. Outcomes of the study might have used as an index by the concern tourism marketers as well as stakeholders for improvement of their service quality and formulating marketing strategies for future directions. In addition, the outcome of the study will contribute a lot in the development of archeological tourism of Bangladesh by identifying important attributes that satisfy the visitors who visit archaeological destinations. The current study will also help tourism planners in developing strategies and friendly tourism policy. Furthermore, the authors are expecting the study will contribute in tourists' satisfaction research.

\section{Research Gaps and Objectives}

Past studies about archaeological tourism and visitor satisfaction have focused on identifying the characteristics, development, and management of archaeological tourism, as well as on investigating 
demographic and travel behaviour characteristics of tourists who visit archaeological destinations. Williams \& Uysal (2010); Pearce \& Balcar (1996) analysed destination characteristics influence visitor satisfaction, development, management, and patterns of demand through an element-by-element comparison of eight heritage sites on the West Coast of New Zealand. Silberberg (1995) provided a common pattern of visitor satisfaction of archaeological tourists by analysing age, gender, income, and educational level. In recent years several studies conducted on visitor satisfaction. Valle et al. (2006) conducted a study for exploring the relationship between travel satisfaction and destination loyalty intention. The study assessed several attributes as the pull factors towards satisfaction. Ahmed et al. (2010) conducted an empirical study which looked at different preferences of the tourist and examine the tour intention in the selection of different tourist destination. But few studies have been conducted only for measuring tourist satisfaction towards a specific destination in Bangladesh (Khuong \& Quyen, 2016). In addition to the mentionable factors mentioned in literature review section, there have some others significant factors and variables which affect tourist satisfaction (Table 1(a) \& 2(b) in appendix). Thus to fill up the gaps this study has carried out and drawn following three objectives-

1. To identify the factors and variables that affect tourist/visitors satisfaction of Paharpur Buddha Vihara.

2. To measure visitors' satisfaction based on explored factors.

3. To provide some recommendations to destination operators for their business policy making.

\section{Literature Review}

Tourism attracts a wide range of academicians, researchers and practitioners attention for its potential contribution to the economic development of any country. Tourism consumer (visitor) opinion about the influencing factors/attributes of the tourism for satisfaction, destination selection, planning, decision making process have not been thoroughly explored and have become a challenging research issue. Having different tourism potentials and advantages, it is quite unfortunate that the country has not yet managed to build a profitable tourism industry. Till now tourism marketers or government are not aware about the needs of the visitors. Retaining darkness about visitor needs, it is not possible to ensure visitor satisfaction. However in recent years, some research works have been done by some researchers regarding visitor satisfaction which ensure tourism development of a country. Satisfaction is the most discussed issue over the 30 years in terms of definition (Truong \& Foster, 2006). Kotler (2012) define satisfaction as a link between perception and expectation. If perception fully match with expectation (perception=expectation), the mental state of this situation is called satisfaction and vice versa situation is called dissatisfaction. Again when the perception will exceeds the expectation (perception>expectation) then delighted mental state is created. Some researchers defined satisfaction simply as the result of customers' assessment of perceived quality (Chi \& Qu, 2008). However, in some papers, quality and satisfaction are modelled as separate constructs (Hui et al., 2007), because the underlying processing mechanisms for evaluating quality and satisfaction are distinct (Zabrak et al., 2010)

In the tourism literature two major approaches are employed to measure visitor satisfaction (Ozedemir et al., 2012). These are disconfirmation theory and performance-only approach (Fallon \& Schofield, 2004). Disconfirmation theory is based on the postpurchase concept, which is a comparison between pre-travel expectations with actual travel experience. Visitor satisfaction is defined as "a collection of visitors' attitudes about specific domains in the vacationing experience (Pizam et al., 1978). Therefore, visitor satisfaction is the overall experience visitors have with the given destination. The performance-only approach considered the visitor satisfaction construct as the visitors' evaluation of destination attributes (Truong \& Foster, 2006; Kozak \& Rimmington, 2000; and Kozak, 2003). The visitors' satisfaction with individual component or attribute of the destination leads to their satisfaction with the overall destination. For this study we considered performance only approach to identify influencing factors of visitor satisfaction. Many different factors may affect the visitor satisfaction: destination attractions, quality of services, safety, previous experience and expectations, tourist activities, destination image, cost, favorable environment and others (Mcdowall, 2010; Petrick, 2004; Kozak, 2001; Prayag, 2009; Al- 
Ababneh, 2013; Valle et al., 2006; Ahmed et al., 2010; Suanmali, 2014) Vetitnev et al. (2013) run a study for examining the factors affecting tourist satisfaction level. The findings of the study indicated that domestic tourists were not completely satisfied with the visit to the destinations. The lowest levels of satisfaction were observed over attributes such as health services, city transport and shops. It was also found that some factors, such as purpose of travel, source of payment for travel choice of accommodation, holiday organization mode and tourists' spending affected tourist satisfaction. This study developed a model which examines the relationships between customer satisfaction, affecting factors and destination loyalty of tourists. Research findings showed that there were strong relationships between those indicators. It was also found that tourists who were satisfied with destinations' attributes are willing to revisit a resort destination.

The study of Al-Ababneh (2013) examined the impact of service quality on tourist satisfaction. This study found that service quality directly impact on tourist satisfaction and service quality plays key role in tourism by increasing level of satisfaction. In this study service quality comprised of three factorsdestination facilities, destination accessibility and destination attraction which positively and negatively affect tourist satisfaction. In the findings the contributor identified that destination facilities (restaurant, souvenir and tour guide) and destination accessibility (maps, parking, toilet) are significant predicator of tourist satisfaction and there have a positive relationship among destination facilities, destination accessibility and satisfaction whereas destination attractions (museum) are moderately positively related to tourist satisfaction. Thiumsak and Ruangkanjanases (2016) implemented a study for identifying the key factors which influence international visitors to revisit. The study discovered that visitors' perceived satisfaction is the main influencing factor to revisit and satisfaction factors are accommodation, shopping, and attitude of local people. The study also found that the above mentioned factors are positively related with revisit intention.

The aim of the study of Khuong \& Quyen (2016) was to measure the key factors affecting international tourists perceived service quality and their return intention towards a specific destination. The study discovered that recreation and entertainment are the strong influential factors whereas some other factors like perceived service quality, culture, history and art, safety and security, local cuisine, negative attributes, perceived price, natural environment, and destination image also had positive effects on international tourist return intention as the tourist are satisfied with the service attribute of the factors. They also mentioned that only one factorinfrastructure negatively effect on tourist return intention. Shahrivar (2012) conducted an extensive literature review based study for investigating the factors that influence tourist satisfaction. The study identified eight attribute factors named natural factors, cultural features, recreation and shopping facilities, accessibility, infrastructure, reception, services, cost and price which affect tourist satisfaction. The study also identified thirty sub attributes. The result of the study showed that the tourist are satisfied with the multiple attributes and dissatisfied with eight attribute whereas in seven rest attributes the tourist are in indifferent position.

Rajes (2013) administered a study for developing a destination loyalty theoretical model by using tourist perception, destination image and tourist satisfaction. In the findings of the study the contributor develop four construct. Tourist satisfaction construct is one of them which influenced by factors entertainments, destination attractions and atmosphere, accommodation, food, transportation services and shopping. This study also reveals that tourist perception, destination image and tourist satisfaction directly influence destination loyalty. Suanmali (2014) administered a study for identifying the major factors affecting tourist satisfaction. The major finding reveals that cost of staying act as the major influencing factors. The other significant factors are environment, hospitality, infrastructure, attraction and accessibility.

\section{METHODOLOGY:}

The purpose of this study is to identify the factors which affect visitors' satisfaction in Paharpur Buddha Vihara. In order to make the research more accurate and to reach its objectives, the quantitative research approach was applied in this study. The study data was collected by using convenient sampling method of 200 respondents. The data obtained from the visitors who visited the Vihara at least for a single time. Total 28 variables are 
comprised the questionnaire. The questionnaires were developed from the major concepts of related literature and from the field study (Table 1(a) in appendix). All questions were based on seven point Likert scale ranging from 1 to 7 , in which 1 is "very strongly disagree" and 7 is "very strongly agree". Principle component factor analysis with varimax rotation (Table 4(d) in appendix) was performed on the survey data. Before that it was found that Kaiser Normalization Sample adequacy 0.730 was acceptable level. Principle components analysis (PCA) is the commonly used method for grouping the variables under few unrelated factors. Variables with a factor loading of higher than 0.6 are grouped under a factor. But only one factor loading 0.592 was considered for its importance with this study. A factor loading is the correlation between the original variable with the specific factor and the key to understand the nature of that particular factor (Dabasish, 2004). After deducting the loading below 0.6 in 6 iterations 5 factors and 15 attributes are finally found out of 28 variables.

\section{FINDINGS AND RESULTS:}

Visitors Socio-Demographic Characteristics: The socio-demographic characteristics and traveled behavior of the sample visitors are presented in Table 5(e) in appendix. The table shows that more than half $(60 \%)$ of the respondents are aged between 21-30 Years and second one (20\%) is less than 20 years. In terms of occupation, nearly half of the respondents are enrolling as student (43.5\%), about quarter of the respondents are enrolling as Government employee $(23.5 \%)$ and private organization employee (27\%). The Table 5(e) also shows that majority of the respondents $(61.5 \%)$ are in graduation level in terms of education and $17 \%$ have been completed this level that means they are in post-graduation level whereas $15 \%$ are in HSC level. In terms of respondents own or their parents' income level, the respondents are so scattered such as $26 \%$ respondents income level are 20,001-25,000 tk., 20\% are $10,001-20,000$ tk., $11.5 \%$ are less than tk 10,000 and the $10.5 \%$ respondents income level is 30,001 35,000 tk.. As shown in the table majority respondents are male (57.5\%) and unmarried (59\%).

The respondents are come from different divisionsRangpur (28\%), Dhaka (24.5\%), Rajshahi (18\%), Barisal (12.5\%), Khulna and Sylhet $(7.5 \%)$ for visiting this archeological site. In case of the question, how many times visited in this place, maximum respondents $(69 \%)$ said that they have visited $2-5$ times and $31 \%$ visited more than 5 times. In the last question of the questionnaire about visiting partner, half $(51 \%)$ of the respondents said that they enjoy to visit with friends and $36.5 \%$ with family. We can conclude in this point that people enjoy to visit in FnF (Friends and Family) way. In the analysis of respondents' socio demographic profile, it is found that young generation has deep passion on visiting different tour destination and they want to visit in the HSC to Graduation level. In addition visitors are said that they visited Paharpur Buddha Vihara repeatedly. Soit may said that the visitors are satisfied as they are visited the destination repeatedly. It is rational that any person who is not satisfied about any destination, he/she will not visit the destination repeatedly.

\section{Influential factors for Visitor Satisfaction (Exploratory Factors Analysis)}

The study result show exploratory factors which affect visitors' satisfaction of Paharpur Buddha Vihara. The variables which are highly related within the group are considered within the factor. The study with 15 variables and 5 factors has been used until reaching the study objectives. The factor analysis result show that five factors influence on visitor satisfaction. The factors are: Destination Attraction, Safety- Security, Favorable Environment, Food Attraction and Cost (Table 1).

Table 1: Factors that influence on visitor satisfaction

\begin{tabular}{|c|l|c|c|c|}
\hline Factor No. & \multicolumn{1}{|c|}{ Factors Name } & Eigen Value & Variance (\%) & Cumulative Variance (\%) \\
\hline $\mathbf{1}$ & Destination Attraction & 3.036 & 20.240 & 20.240 \\
\hline $\mathbf{2}$ & Safety- Security & 2.761 & 18.410 & 38.650 \\
\hline $\mathbf{3}$ & Favorable Environment & 1.216 & 8.108 & 46.758 \\
\hline $\mathbf{4}$ & Food Attraction & 1.171 & 7.804 & 54.561 \\
\hline $\mathbf{5}$ & Cost & 1.088 & 7.250 & 61.812 \\
\hline
\end{tabular}


The above influencing factors explain $61.81 \%$ variance of collected data set. The most important factor that influence on visitor satisfaction is destination attraction. The Eigen Value of this factor is 3.036 with $20.24 \%$ of variance. The second most important factor is safety-security at the destination, which has the Eigen value 2.761 with $18.41 \%$ of variance. The third important factor that plays important role to influence on visitor satisfaction is favorable environment bearing Eigen value 1.216 with variance $8.108 \%$ followed by food attraction and cost with 1.171 and 1.088 Eigen value and variance $7.804 \%$ and $7.250 \%$.

From the output of rotated component matrix (Table 4(d) in appendix) it is found that factor one Destination Attraction leads the variables Attractive archaeological symbol with factor loading 0.774 which indicates higher level of correlation of the variables with factors.

Table 2: Destination attraction

\begin{tabular}{|l|c|}
\hline \multicolumn{1}{|c|}{ Variables Name } & Factors Loading \\
\hline $\begin{array}{l}\text { Attractive archaeological } \\
\text { symbol }\end{array}$ & 0.774 \\
\hline $\begin{array}{l}\text { Wonderful diversity in } \\
\text { historical structure (church, } \\
\text { castle, temple) }\end{array}$ & 0.766 \\
\hline $\begin{array}{l}\text { Attractive Buddhist stupa in } \\
\text { the center }\end{array}$ & 0.712 \\
\hline $\begin{array}{l}\text { Great historical importance of } \\
\text { the destination }\end{array}$ & 0.697 \\
\hline $\begin{array}{l}\text { Attractive architectural beauty } \\
\text { of the destination }\end{array}$ & 0.592 \\
\hline
\end{tabular}

The second highest correlation of the variable with factor is Wonderful diversity in historical structure with loading 0.766 which indicates that structural beauty of historical architecture influence on visitor satisfaction. More or less for this reason, we notice lots of picture or selfi in front of Paharpur Buddha Vihara, Tazmohal and other attractive architectural sites. Like these it is observed that variables: Attractive Buddhist stupa in the center with loading 0.712 , Great historical importance of the destination 0.697, and Attractive architectural beauty of the destination factor loading 0.592 have the good correlation with the factor that indicate visitor satisfaction is influenced by these attributes. Visitors are influenced by this factor for their curiosity mind.
By nature, people are little bit weak to know the history and culture. Archaeological tourist destinations provide the opportunity to know about the glorious history and culture and visitors visit the destination for this attraction. This outcome is supported by many previous researchers (AlAbabneh, 2013; Valle et al., 2006; Khuong \& Quyen, 2016; Shahrivar, 2012; Rajes, 2013; and Suanmali, 2014).

The second most important factor which influence on visitor satisfaction is safety security of the destination which lead the variables neat and clean destination with loading 0.754 , safety food served at the destination with loading 0.737 , non-smoking place loading 0.711 and up to mark security of the destination with loading 0.680 (Table 3).

Table 3: Safety- security

\begin{tabular}{|l|c|}
\hline \multicolumn{1}{|c|}{ Variables Name } & Factors Loading \\
\hline Neat and clean destination & 0.754 \\
\hline Safety food at the destination & 0.737 \\
\hline Non-smoking place & 0.711 \\
\hline $\begin{array}{l}\text { Up to mark security of the } \\
\text { destination }\end{array}$ & 0.680 \\
\hline
\end{tabular}

Actually visitors do not want to visit unsecure and unsafe place. If we observe about visitors arrival in our country after the 01 July 2016 (unwanted terrorist attack at Holly Artizen Restaurant), we notice that the tourist arrival are dramatically decreased. In 2014, UNESCO declared world heritage site Palmyra in Iraqis now out of tourist which attacked by Islamic State (IS) militant group in 2013. The outcome is also supported by many previous researchers (Vetitnev et al., 2013; AlAbabneh, 2013; Valle et al., 2006; Ahmed et al., 2010; Khuong \& Quyen, 2016; and Rajes, 2013).

Table 4: Favorable environment

\begin{tabular}{|l|c|}
\hline \multicolumn{1}{|c|}{ Variables Name } & Factors Loading \\
\hline $\begin{array}{l}\text { Sound, noiseless \& quite } \\
\text { place }\end{array}$ & 0.772 \\
\hline $\begin{array}{l}\text { Spacious and chaos free roads } \\
\text { facilities }\end{array}$ & 0.731 \\
\hline
\end{tabular}

The factor favorable environment is highly correlated with the variables. This factor plays important role to visitor satisfaction for taking travel decision. Most of the visitors come to visit the 
destination with family, friends and relatives and they want relax and comfortable environment. Favorable environment ensures visitor satisfaction through calm and chaos free atmosphere. This factor consist of two variables name sound, noiseless and quite place loading 0.772 and spacious and chaos free roads facilities loading 0.731 (Table 4). The outcome is also supported by many previous researchers like Valle et al., 2006; Ahmed et al., 2010; Rajes, 2013; and Suanmali, 2014.

Table 5: Food attraction

\begin{tabular}{|l|c|}
\hline \multicolumn{1}{|c|}{ Variables Name } & Factors Loading \\
\hline $\begin{array}{l}\text { Available local foods at the } \\
\text { restaurant }\end{array}$ & 0.744 \\
\hline Available Preferable food & 0.632 \\
\hline
\end{tabular}

It is found that food attraction is correlated with the variables available local foods at the restaurant loading 0.744 and available preferable foods loading 0.632. Every area of any country is enriched with famous local foods. In Bangladesh, Natore district is famous for Kaca Golla, Bografor Yogurt, Netrokona district for Pillow Sweet. Alike Rajshahi region is famous for KalaiRuti.

Visitors who visited in a specific destination or area taste local foods of that area. Availability of local and preferable foods can ensure visitor satisfaction. This factor is supported by different previous studies (Valle et al., 2006; Ahmed et al., 2010; Rajes, 2013; Shahrivar, 2012; and Huh, 2002).

Table 6: Cost

\begin{tabular}{|l|c|}
\hline \multicolumn{1}{|c|}{ Variables Name } & Factors Loading \\
\hline Reasonable food price & 0.699 \\
\hline Affordable transportation cost & 0.697 \\
\hline
\end{tabular}

This factor consists of two attributes which are highly correlated with the factor namely reasonable food price at the destination loading 0.699 and affordable transportation cost loading 0.697 (Table 6). In tourism most of the visitors spend their pocket money for mental satisfaction and they do not want to spend in unfruitful or useless means (way). For this, visitors consciously evaluate price and cost of any particular destination. This factor is supported by different tourism related studies (Vetitnev et al., 2013; Thiumsak and Ruangkanjanases, 2016;
Ahmed et al., 2010; Shahrivar, 2012; and Suanmali, 2014).

\section{DISCUSSION:}

This Paragraph is briefly addressed the main findings of the study. The study has been identified 5 influencing factors of visitor satisfaction. In this study, contributors have also considered several leading variables which influence visitor satisfaction. Out of twenty eight variables fifteen variables likeAttractive archaeological symbol, Wonderful diversity in historical structure (church, castle, temple), Attractive Buddhist stupa in the center, Great historical importance of the destination, Attractive architectural beauty of the destination, Neat and clean destination, Safety food at the destination, Non-smoking place, Up to mark security of the destination, Sound, noiseless \&quite place, Spacious and chaos free roads facilities, Available local foods at the restaurant, Available Preferable food, Reasonable food price and Affordable transportation cost were considered as leading variables. It is also found that archaeological attraction is the prime factor that correlated with variables. The other factors are safety-security, favorable environment, food attraction and cost. It was observed from the tourism and satisfaction related literature if visitors get the expected services after visiting any destination, they become highly satisfied and have made revisit intention.

\section{Implications of the Research Findings}

This study has been focused on identification of different factors and variables influencing visitor satisfaction. Accordingly, the managerial implications of this study are more focused on a discussion of this finding, rather than focusing on a discussion of the influence of the perceived tourism development. The research findings may help tourism planners, developers and policy makers to understand what the key tourism players (visitors) prefer to develop in tourism attractions/resources and to plan and implement successful competitive strategies. The results are likely to help tourism stakeholders and marketers to collect information and plan appropriate competitive strategies based on the mentioned five factors, which they prefer to develop. The Archeological attraction, safetysecurity, favorable environment, local food attraction and cost of services might be recommended as 
specific marketing plans for destination competitive strategies. These marketing strategies may enable tourism destinations to achieve a maximum correlation with visitors' demand to meet their wants and needs. However the archaeological tourism is little bit different from general tourism, the managers will get proper idea from this study about the way to satisfy visitors of archaeological tourism. More specific implication, this study may be helpful to the management authority of Paharpur Buddha Vihara to take decision according to the identifying factors which affect visitor satisfaction. This study will also helpful to rethink them to formulate future plan for the archaeological sites. Tourism industry will get some idea relevant to visitor satisfaction towards archaeological tourism and it will be helpful for them to conduct tourism business. Again, students may get idea from the study about systematic quantitative analysis and decision making.

\section{CONCLUSIONS AND RECOMMENDATIONS:}

The main objective of this study was to identify factors influencing visitor satisfaction. In order to achieve the study objective, the study explores and adopts 5 exploratory factors. These are Archeological attraction, safety-security, favorable environment, Local food attraction and cost of services. The factors are highly related with some influential variables like Attractive archaeological symbol, Neat and clean destination, Up to mark security of the destination, Sound ,noiseless \&quite place, Available local foods at the restaurant, and Reasonable food price. Intensive literature review and field study help to explore the factors and variables. The factor archaeological attraction is considered as the most influential factor by the visitors of Paharpur Buddha Vihara. The most attractive factors of any archaeological sites are its history, sophisticated design and architectural beauty. The Vihara consists all of these. So the authority should preserve different archaeological sites for attracting visitor. Besides safety security must be considered as the most influential factor. Law enforces agencies should present and run campaign after some interval which will increase visitor's confidence level. Cost of services should make reasonable for the visitors. As maximum visitors of this destination are the students, different discount or incentives may motivate them to visit such type of destinations. Favorable environment makes favorability to tourism. As earlier mentioned, visitors spend for mental peace. Thus they like peaceful, noiseless, calm environment. So destination authority should be concern making environment favorable to the visitors. The local transportation facilities and cost should be developed and make safe. For developing the tourism industry in Bangladesh, the authority should increase the number of offers and widen the extent of services factors for the visitors. Tour operators both in private and public sectors should offer alternative packages for tour programs. The tourism development related people should arrange some tourism components based on nature, traditions and culture. Above all, the specific factors that explored through literature review and field study must be managed by the destination operators for highest visitor satisfaction.

\section{Limitations and further Research}

This study can be considered as a useful information and guidance for tourism related decisions. However the research has some limitations. Firstly, this study conducted by applying only 15 variables in the exploratory phase. There may have other variables in other context. Secondly, a sample of 200 visitors and only one destination was considered for this study which might not enough for generalization of archaeological tourism. Thirdly, in current tourism markets any destination need to pay more attention to advanced technologies for delivering services to the tourist effectively and efficiently, which is absolutely ignored. Therefore, further studies may address visitor satisfaction variables that include information technology. Fourthly, the influential factors were formed based on authors' judgment with supports of literature and field study which may not always rational. Finally we have identified five factors influencing visitor satisfaction but cannot say which attribute or variable is significant for visitor satisfaction. Analysis of variance can help to overcome this limitation where Duncans' Multiple Range test can help for actual prediction, which is ignored here. Therefore future research may be conducted by considering these limitations.

\section{REFERENCES:}

1. Ahmed A., Azam S. M., \& Bose T. K. (2010). Factors Affecting the Selection of Tour Destination in Bangladesh: An 
Empirical Analysis. International Journal of Business and Management. 5(3), 52-61.

2. Al-Ababneh M. (2013). Service Quality and its Impact on Tourist Satisfaction. Interdisciplinary Journal of Contemporary Research in Business.4(12), 164-177. https://journal-archieves31.webs.com/164177.pdf

3. B. G. Tabachnick and Fidell, L. S. (2001). Using Multivariate Statistics, $4^{\text {th }}$ ed. New York: Harper Collins.

4. Chen, C. and Tsai, D. (2007). How destination image and evaluative factors affect behavioral intentions. Tourism Management. 28(4): 1115-1122.

https://doi.org/1115-1122.10.1016/j.tourm an.2006.07.007

5. Chowdhury A. S. M., Ullah M. M., \& Hassan R. M. (2013). Impact of Tourism in Bangladesh Economy. World Journal of Social Sciences.3(6): 45-57.

6. Chi, C.G. and Qu H. (2008). Examining the structural relationships of destination image, tourist satisfaction and destination loyalty: An integrated approach. Tourism Management, 1(29): 624-636.

https://doi.org/10.1016/j.sbspro.2015.01.1198

7. Debasish, S., S. (2004). Exploring Customer Preference for Life Insurance in India Factor Analysis Method, Vilakshan.1(1), 9-20.

8. Fallon, P. and P. Schofield, (2004). Just Trying to Keep the Customer Satisfied. Journal of Quality Assurance in Hospitality and Tourism, 4(3-4): 77-96.

9. Hassan, R. M., Ullah, M. M., \& Chowdhury, A. S. M. (2013). Impact of Tourism in Bangladesh Economy World Journal of Social Sciences, 3(4); 228-240.

10. Hair, J.F., Anderson, R.E., Tatham, R.L. \& Black, W.C. (1998). Multivariate data analysis $\left(5^{\text {th }}\right.$ ed.). Prentice Hall.

11. Hui, T.K., D. Wan and Ho A. (2007). Tourists' satisfaction, recommendation and revisiting Singapore. Tourism Management, 28: $965-975$. https://doi.org/10.1016/j.tourman.2006.08.008

12. Khuong N. M., \& Quyen P. N. (2016). Factors Affecting International Tourists' Perceived Service Quality and Return Intention-A Study in Ho Chi Minh City,
Vietnam. Review of European Studies; 8(3). ISSN 1918-7173 E-ISSN 1918-7181.

13. Kotler P., \& Gary A. (2012). Principles of Marketing. $14^{\text {th }}$ edition Pearson Prentice Hall One Lake Street, Upper Saddle River, New Jersey.

14. Kozak, M. and Rimmington M. (2000). Tourist satisfaction with Mallorca Spain, as an off-season holiday destination. Journal of Travel Research, 38(1): 260-269. https://doi.org/10.1177/004728750003800308

15. Kozak, M., (2003). Measuring Tourist Satisfaction With Multiple Destination Attributes. Tourism Analysis, 7: 229-240.

16. Bartlett, M., S. (1954). A note on multiplying factors for various chi-squared approximations. Journal of the Royal Statistical Society. 16(B): 296-298.

17. Moutinho, L., T., Albayrak and Caber, M., (2012). How Far does Overall Service Quality of a Destination Affect Customers' Post-Purchase Behaviours? International Journal of Tourism Research, 14: 307-322.

18. McDowall, S. (2010). International Tourist Satisfaction and Destination Loyalty: Bangkok, Thailand, Asia Pacific Journal of Tourism Research, 15(1), 21-42. https://doi.org/10.1080/10941660903510040

19. Ozdemir, B., Çizel B., and Cizel, R.B. (2012). Satisfaction With All-Inclusive Tourism Resorts: The Effects of Satisfaction With Destination and Destination Loyalty, International Journal of Hospitality and Tourism Administration, 13(20): 109-130.

20. Prayag, G. (2009). Tourists' Evaluations of Destination Image, Satisfaction, and Future Behavioral Intentions-The Case Of Mauritius, Journal of Travel \& Tourism Marketing, 26: 8, 836-853.

https://doi.org/10.1080/10548400903358729

21. Petrick, F. J., (2004). The Roles of Quality, Value, and Satisfaction in Predicting Cruise Passengers' Behavioral Intentions, Journal of Travel Research, 42(4). https://doi.org/10.1177/0047287504263037

22. Pizam, A., Y. Neumann and A. Relchel, (1978).Dimensions of tourist satisfaction with a destination area. Annals of Tourism Research, 5(3): 314-322. 
23. Rahman W. M. (2012). Cultural Tourism and Bangladesh: An Overview. Bangladesh Research Publications Journal. 7(1): 06-15.

24. Rekha S. R. \& Sardar S., (2016).Students' Attitude towards Beach Tourism in Bangladesh: A Study on Saint Martin and Cox's Bazar Sea Beaches. Bangladesh Journal of Tourism. 1(1); 27-40.

25. Rajesh R. (2013). Impact of Tourist Perceptions, Destination Image and Tourist Satisfaction on Destination Loyalty: A Conceptual Model Revista de Turismo y Patrimonio Cultural. 11(3): 67-78. https://doi.org/10.25145/j.pasos.2013.11.039

26. Roy, S.C. \& Roy, M. (2015). Tourism in Bangladesh: Present Status and Future Prospects. Journal of International Business Research and Marketing, 1(8), 53-61.

27. Silberberg, T. (1995). Cultural tourism and business opportunities for museums and heritage sites. Tourism Management. 16(5); 361-365. https://doi.org/10.1016/0261-5177(95)0039-Q

28. Shahrivar B. R. (2012). Factors that influence tourist satisfaction. Journal of Travel and Tourism Research, Special Issue.

29. Suanmali S. (2014). Factors Affecting Tourist Satisfaction: An Empirical Study in the Northern Part of Thailand. SHS Web of Conferences.12, 0102 (2014). https://doi.org/10.1051/shsconf/20141201027

30. Truong, T. and D. Foster, (2006).Using HOLSTAT to evaluate tourist satisfaction at destinations: The case of Australian holidaymakers in Vietnam. Tourism Management, 27(5): 842-855.

31. Tuhin W., Kashedul M., \&Majumder H. T. M., (2011).An Appraisal of Tourism Industry Development in Bangladesh. European Journal of Business and Management. 3(3), 2011. www.iiste.org

32. Thiumsak T. and Ruangkanjanases A. (2016). Factors Influencing International Visitors to Revisit Bangkok, Thailand. Journal of Economics, Business and Management. 4(3), 220-230. https://doi.org/10.7763/JOEBM.2016.V4.394

33. Valle P. O. D., Silva J. A., Mendes J., Guerreiro M. (2006). Tourist Satisfaction and Destination Loyalty intention: A
Structural and Categorical Analysis. International Journal of Business Science and Applied Management, 1(1), 2006.

34. Vetitnev A., Romanova G., Matushenko N., and Kvetenadze E. (2013). Factors Affecting Domestic Tourists' Destination Satisfaction: The Case of RussIa Resorts. World Applied Sciences Journal, 22(8): 1162-1173, 2013. https://doi.org/10.5829/idosi.wasj.2013.22.08. $\underline{27513}$

35. Wang, S. and H. Qu, 2006. A Study of Tourists' Satisfaction Determinants in the Context of the Pearl River Delta SubRegional Destinations, Journal of Hospitality and Leisure Marketing, 14(3): 49-63.

36. Williams, A. J., \& Uysal, M. (2010).Current Issues and Development in Hospitality and Tourism Satisfaction, Routledge, Taylor and Francis Group, Newyork and London.

37. Yoon, Y. and M. Uysal, 2005. An examination of the effects of motivation and satisfaction on destination loyalty: A structural model. Tourism Management, 26(1): 45-56.

https://doi.org/10.1016/j.tourman.2003.08.016

38. Zabkar, V., M. M. Brencic, and Dmitrovic T. (2010). Modeling perceived quality, visitor satisfaction and behavioral intentions at the destination level. Tourism Management, 31: 537-546.

\section{Websites:}

\section{World Travel and Tourism Council (WTTC)}

$>$ Wttc (2020).Travel \& Tourism Economic Impact 2018 Bangladesh. Retrieved From: Https://Www.Wttc.Org/Economic-Impa ct/Country-Analysis/Country-Reports/.

Retrieved On: 28.02.2020.

$>$ WTTC (2020).Monthly Economic Impact. Retrieved From: https://www.wttc.org/ economic-\%20impact/monthly-updates/. Retrieved on: 28.02.2020.

\section{UNESCO}

> UNESCO (2018). https://whc.unesco.org/ en/list/322/, and http://whc.unesco.org/en/ list/322. Retrieved on: 28.02.2020. 


\section{APPENDIX:}

Table 1(a): Review of related literatures

\begin{tabular}{|c|c|c|}
\hline \multirow[t]{2}{*}{ Factors \& Variables } & \multicolumn{2}{|r|}{ Source } \\
\hline & Field Study & Literature Support \\
\hline Archaeological symbol attracts me & $\sqrt{ }$ & $x$ \\
\hline Buddhist stupa in the centre attracts & $\sqrt{ }$ & $x$ \\
\hline Architectural beauty & $\sqrt{ }$ & \multirow{3}{*}{$\begin{array}{l}\text { Al-Ababneh (2013); Valle et al. (2006); Khuong \& } \\
\text { Quyen (2016); Shahrivar (2012); Rajes (2013); and } \\
\text { Suanmali (2014). }\end{array}$} \\
\hline $\begin{array}{l}\text { Wonderful diversity in historical structure } \\
\text { (church, castle, temple) }\end{array}$ & $x$ & \\
\hline Great historical importance & $x$ & \\
\hline The destination is neat and clean & $\sqrt{ }$ & $x$ \\
\hline It is non-smoking place & $\sqrt{ }$ & $x$ \\
\hline Up to the mark security in destination & $x$ & \multirow{4}{*}{$\begin{array}{l}\text { Vetitnev et al., 2013; Al-Ababneh, 2013; Valle et } \\
\text { al., 2006; Ahmed et al., 2010; Khuong \& Quyen, } \\
\text { 2016; and Rajes, } 2013 .\end{array}$} \\
\hline Safety food at the destination & $x$ & \\
\hline Local foods are available at the restaurant & $\sqrt{ }$ & \\
\hline Preferable food are available & $x$ & \\
\hline Sound, noiseless \& quite place & $\sqrt{ }$ & $x$ \\
\hline Spacious and chaos free roads facilities & $\sqrt{ }$ & $x$ \\
\hline Affordable transportation cost & $x$ & \multirow{2}{*}{$\begin{array}{l}\text { Vetitnev et al., 2013; Thiumsak and } \\
\text { Ruangkanjanases, 2016; Ahmed et al., 2010; } \\
\text { Shahrivar, 2012; and Suanmali, } 2014 .\end{array}$} \\
\hline $\begin{array}{l}\text { Reasonable price charges at the } \\
\text { destination }\end{array}$ & $\sqrt{ }$ & \\
\hline
\end{tabular}

Table 2(b): Factors that influence visitor satisfaction

\begin{tabular}{|c|c|c|c|c|}
\hline Factor No & Factors Name & Eigen Value & Variance (\%) & Cumulative Variance (\%) \\
\hline $\mathbf{1}$ & Archaeological Attraction & 3.036 & 20.240 & 20.240 \\
\hline $\mathbf{2}$ & Safety- Security & 2.761 & 18.410 & 38.650 \\
\hline $\mathbf{3}$ & Favorable Environment & 1.216 & 8.108 & 46.758 \\
\hline $\mathbf{4}$ & Local Food Attraction & 1.171 & 7.804 & 54.561 \\
\hline $\mathbf{5}$ & Cost of the services & 1.088 & 7.250 & 61.812 \\
\hline
\end{tabular}

Table 3(c): Reliability co-efficient

\section{KMO and Bartlett's Test}

Kaiser-Meyer-Olkin Measure of Sampling Adequacy.

Bartlett's Test of Sphericity

\begin{tabular}{|l|r|}
\hline Approx. Chi-Square & 662.793 \\
\hline df & 105 \\
\hline Sig. & 0.000 \\
\hline
\end{tabular}

Table 4(d): Rotated component matrix and total variance explained

\begin{tabular}{|c|c|c|c|c|c|}
\hline \multirow{2}{*}{ Attributes } & \multicolumn{5}{|c|}{ Component } \\
\hline & 1 & 2 & 3 & 4 & 5 \\
\hline Archaeological symbol attracts me to visit the destination & 0.774 & -0.040 & -0.032 & 0.049 & 0.062 \\
\hline $\begin{array}{l}\text { The destination has wonderful diversity in historical } \\
\text { structure(church, castle, temple) }\end{array}$ & 0.766 & 0.039 & 0.066 & 0.102 & 0.076 \\
\hline $\begin{array}{l}\text { Buddhist stupa in the center attracts me to visit the } \\
\text { destination }\end{array}$ & 0.712 & -0.060 & 0.107 & -0.023 & 0.024 \\
\hline This destination has a great historical importance & 0.697 & -0.103 & 0.065 & -0.039 & 0.103 \\
\hline Architectural beauty of the destination attracts me & 0.592 & 0.009 & 0.445 & -0.066 & -0.181 \\
\hline The destination is neat and clean & -0.105 & 0.754 & -0.073 & -0.304 & 0.013 \\
\hline Safety food are served at the destination & -0.006 & 0.737 & -0.070 & 0.147 & 0.218 \\
\hline
\end{tabular}




\begin{tabular}{|c|c|c|c|c|c|}
\hline It is non-smoking place & -0.088 & 0.711 & 0.212 & 0.116 & -0.094 \\
\hline Security of the destination is up to the mark for visitor & 0.026 & 0.680 & 0.166 & 0.276 & 0.139 \\
\hline It is sound ,noiseless \& quite place & 0.171 & 0.250 & 0.772 & 0.015 & -0.049 \\
\hline Spacious and chaos free roads facilities & 0.059 & -0.075 & 0.731 & 0.144 & 0.339 \\
\hline Local foods are available at the restaurant & 0.124 & 0.022 & 0.253 & 0.744 & -0.097 \\
\hline Varieties of food & -0.119 & 0.397 & -0.245 & 0.632 & 0.236 \\
\hline $\begin{array}{l}\text { Reasonable price charges at the destinationfor food and } \\
\text { other recreation }\end{array}$ & 0.022 & 0.237 & 0.004 & 0.245 & 0.699 \\
\hline Transportation cost is affordable to visit the destination & 0.203 & -0.006 & 0.177 & -0.327 & 0.697 \\
\hline Eigen Value & 3.036 & 2.761 & 1.216 & 1.171 & 1.088 \\
\hline$\%$ of Variance & 20.240 & 18.410 & 8.108 & 7.804 & 7.250 \\
\hline Cumulative $\%$ & 20.240 & 38.650 & 46.758 & 54.561 & 61.182 \\
\hline
\end{tabular}

Notes: Extraction Method: Principal Component Analysis. Rotation Method: Varimax with Kaiser Normalization. A Rotation converged in 6 iterations. 5 Components extracted

Table 5(e): Demographic profile of respondents

\begin{tabular}{|c|c|c|}
\hline Demographic Characteristics & Frequency & Percent (\%) \\
\hline \multicolumn{3}{|c|}{ Age of Respondent } \\
\hline Less than 20 Yrs. & 40 & 20.0 \\
\hline $21-30$ Yrs. & 120 & 60.0 \\
\hline 31-40 Yrs. & 26 & 13.0 \\
\hline 41-50 Yrs. & 5 & 2.5 \\
\hline $51-60$ Yrs. & 8 & 4.0 \\
\hline 60 Yrs. or more & 1 & 0.5 \\
\hline \multicolumn{3}{|c|}{ Profession } \\
\hline Student & 87 & 43.5 \\
\hline Govt. Employee & 47 & 23.5 \\
\hline Private Organization Employee & 54 & 27.0 \\
\hline Housewife & 8 & 4.0 \\
\hline Business Man & 4 & 2.0 \\
\hline \multicolumn{3}{|c|}{ Education } \\
\hline SSC Level & 10 & 5.0 \\
\hline HSC Level & 30 & 15.0 \\
\hline Graduation Level & 123 & 61.5 \\
\hline Post-Graduation Level & 34 & 17.0 \\
\hline More & 3 & 1.5 \\
\hline \multicolumn{3}{|c|}{ Income Level } \\
\hline Less than Tk.10, 000 & 23 & 11.5 \\
\hline $10,001-20,000$ & 40 & 20.0 \\
\hline $20,001-25,000$ & 52 & 26.0 \\
\hline $25,001-30,000$ & 18 & 9.0 \\
\hline $30,001-35,000$ & 21 & 10.5 \\
\hline $35,001-40,000$ & 17 & 8.5 \\
\hline $40,001-45000$ & 18 & 9.0 \\
\hline $45001-50000$ & 7 & 3.5 \\
\hline 50,000 or More & 4 & 2.0 \\
\hline \multicolumn{3}{|c|}{ Gender } \\
\hline Male & 115 & 57.5 \\
\hline Female & 85 & 42.5 \\
\hline \multicolumn{3}{|c|}{ Marital Status } \\
\hline Unmarried & 118 & 59.0 \\
\hline Married & 82 & 41.0 \\
\hline \multicolumn{3}{|c|}{ Division } \\
\hline
\end{tabular}




\begin{tabular}{|c|c|c|}
\hline Rajshahi & 36 & 18.0 \\
\hline Rangpur & 56 & 28.0 \\
\hline Dhaka & 49 & 24.5 \\
\hline Khulna & 14 & 7.0 \\
\hline Chittagong & 5 & 2.5 \\
\hline Sylhet & 15 & 7.5 \\
\hline Barisal & 25 & 12.5 \\
\hline \multicolumn{3}{|c|}{ How Many Times Visited This Place } \\
\hline $2-5$ times & 138 & 69.0 \\
\hline 5 or more times & 62 & 31.0 \\
\hline \multicolumn{3}{|c|}{ Visited With } \\
\hline Friends & 102 & 51.0 \\
\hline Family & 73 & 36.5 \\
\hline Colleague & 18 & 9.0 \\
\hline Others & 7 & 3.5 \\
\hline
\end{tabular}

Citation: Sardar S, Hossain ME, Hossain MI, and Islam MS. (2020). Factors affecting visitors satisfaction: an empirical study on the Paharpur Buddha Vihara, Naogaon, Rajshahi, Int. J. Manag. Account. 2(4), 6173. https://doi.org/10.34104/ijma.020.061073 